\title{
Bank Image Structure: The Relationship to Consumer Behaviour
}

\author{
- Lukášová Rưžena, Urbánek Tomáš
}

\begin{abstract}
This paper presents the results of a study of the relationship between the bank image, its structure as a reflection in the minds of individuals and behavioural tendencies in relation to banks. Attitudinal scales were used to identify the contents of the particular banks' image. The structure of the image was identified by means of factor analysis. The study found that the respondents' behavioural tendencies, i.e. their willingness to be a client of or to recommend a particular bank, are related to different content components of particular banks and mainly to respondents' needs. Based on the results, the study identifies the danger that the results of the bank image analysis can be misinterpreted if the respondents' relationship to the bank is underestimated.
\end{abstract}

Keywords: financial services marketing, bank image, image structure

JEL: G21, L84, M31

\section{INTRODUCTION}

The corporate image, defined as "the commonly held perception of an organisation by a group or groups" (Balmer, 1995, p. 25) or "the net result of the interaction of all experiences, impressions, beliefs, feelings and knowledge people have about a company" (Worcester, 1997, p. 147), has been in the focus of marketing specialists - especially in various sectors of services - for many years. The importance attributed to corporate image in the financial services sector stems mainly from the fact that the corporate image is viewed as a strong instrument for influencing customers. In a situation when there are only marginal differences in prices and consumers are being flooded with increasing volumes of information, the image as an "impression created at a particular time at a particular level of abstraction" (Cornelissen, 2000) more and more assumes the role of the factor that makes customers' orientation subjectively easier and their decisions simpler. Moreover, in the financial services sector the acquisition of a strong corporate image represents the most effective type of differentiation (Balmer \& Stotvig, 1997).

If we define consumer behaviour as activities realized in the process of selecting, purchasing and using products and services, then the role of the bank image in relation to consumer behaviour is relatively complicated. From the point of view of consumers' behaviour research, the image may be viewed either as an independent variable, i.e. the customers' behaviour determinant (the bank image influences decisions of customers), as a dependent variable (it is a result of the customer's experience with the bank and a reflection of the degree of their satisfaction or dissatisfaction) and of course also as an intervening variable (it works as a filter which influences the perception of the bank and judging of the information concerning the bank). The image thus may be studied in many contexts. 
While at the initial stages of research into corporate image attention was mainly paid to its influence over consumer decisions and to image creation through marketing communication, later the attention of many authors writing about the services sector shifted to the relationship between corporate image and customer loyalty (e.g. Nguyen \& LeBlanc, 1998; Andreassen \& Lindestad, 1998; Hart \& Rosenberger III, 2004; Jha, Deitz, Babakus \& Yavas, 2013; Wang, 2010; Neset, Nervik \& Helgesen, 2011; Onyancha, 2013 and others), consumer trust (e.g. Flavián, Guinaliu \& Torres, 2005), customer satisfaction (e.g. Bloemer, De Ruyter \& Peeters, 1998; Minkiewicz, Jody \& Mavondo, 2011), service quality (e.g. Akroush, 2008; Cameran, Moiser $\&$ Pettinicchio, 2010) and their mutual relationships. However, the research results achieved are not completely consistent and - as stated in Hu, Kandampully \& Juwaheer (2009, p. 11) - "although previous studies have addressed the importance of service quality, satisfaction, perceived value, and image, the precise nature of the relationships that exist between these constructs and the understanding of their effect on customer behaviour still remains a key issue".

As far as banking services are concerned, publications in as early as in the 1990s indicated that the relationship between image, quality, customer satisfaction and loyalty may be influenced by the nature of the relationship towards the bank (e.g. Bloemer, De Ruyter \& Peeters, 1998), which can differ depending on whether the relationship is determined more by cognitive or by affective factors. Moreover, personal relationship with the bank is, as Ivarsson (2005, in Beradovic, Hultés \& Pettersson, 2006, p. 6) found out, "the factor of most importance for clients at an abstract level". Understanding the image as the impression created at a particular time at a particular level of abstraction (Cornelissen, 2000), it appears to be necessary to better understand the character of customers' relationship to banks and the consequences of this relationship for consumer behaviour.

With respect to the fact that "corporate image is formed in a consumer's mind through a procedure whereby information is processed and organized into meaning on the basis of stored categories" (LeBlanc \& Nguyen, 1996), it is necessary to view the image from the receiver's perspective when looking for relations between the character of consumer's relationship to the bank and the consumer's behaviour, i.e. the bank image must be perceived and studied as a reflection in an individual's mind. In doing so, it may be beneficial to look for the internal structure of image as a reflection in an individual's mind and reveal the relationships between its components and behavioural tendencies of customers.

\section{IMAGE STRUCTURE}

In available literature, we found no generally accepted definition of a bank image structure as a reflection in the mind of an individual, although certain findings about individual components of the image have been published. Kennedy (1977, in Nguyen \& LeBlanck, 1998) differentiated between the functional and the emotional components of the image; he associated the functional component with tangible cues and the emotional component with psychological states that are manifested by feelings and attitudes. According to De Pelsmacker et al. (2000, in Akm \& Demirel, 2011) image is composed of three dimensions: beliefs as the cognitive dimension of the attitude, emotional feelings as the affective component of the attitude, and behavioural intention. 
Van Heerden and Puth (1995) tried to find perception dimensions of the corporate image of financial institutions. Using the factor analysis of the data acquired by the semantic differential method, they identified four dimensions they called dynamism, stability / credibility, client / customer service and visual identity. Flavián et al. (2004; 2005, in Bravo, Montaner \& Pina, 2009) considered the access to service, service offering, personal contact, security and reputation to be the main dimensions of corporate image in the financial sector. Pruyn (in Cornelissen, 2000) and Cornelissen (2000) pointed out that the degree to which an image is processed and structured as a reflection in the mind may be different in different individuals as well as groups depending on their level of involvement and therefore, the structure of the bank image in the individual's mind can differ in this regard.

\section{STUDY}

\subsection{Objectives}

The objectives of the study whose results are presented in this article was to find out what relationship, if any, exists between the content of a bank image, the structure of the bank image as a reflection in the respondents' mind, and their behavioural tendencies towards that bank. Four banks operating on the Czech market were selected for the study. In selecting the banks the authors chose some that are well-known to the respondents and some less well-known, those that are similar to each other in some respects and dissimilar in others.

Because of the non-commercial character of the study, the banks referred to in the article are identified by numbers rather than by names.

Objectives of the study were:

- to define the image of each of the banks under investigation

- to identify respondents' behavioural tendencies to individual banks

- to compare behavioural tendencies of respondents with the image content of each of the banks

- to identify the internal structure of the image of individual banks and to trace links between behavioural tendencies and identified structural components of the image.

\subsection{Methods}

The study was based on two questionnaires designed in such a way that the battery of questions covered three components in the respondents' attitudes towards the bank, i.e. the cognitive, affective and the conative components (behavioural tendencies).

One of the questionnaires contained bank attributes of banks defined as attributes of a mainly cognitive character (27 items in total), two items inquiring about the degree of personal and mediated experience with the bank, and two questions on respondents' behavioural tendencies. The other questionnaire used in the study (42 items in total) was based on the semantic differential method, and it was intended primarily to identify the affective (or mainly affective) aspects of the bank image and to identify the respondents' perception of the positions of the banks in the market. 
Items 1 through 27 of the first questionnaire consisted of statements about the banks' facilities, their management, advertising, the content and quality of their services, service fees, etc. The attributes were selected on the basis of published studies (Yavas \& Shemwell, 1996) and on the basis of results of a pilot study. Using a five-point Likert-type scale, the respondents were asked to indicate for individual banks to what extent they agreed with the statement $(-2=$ I certainly disagree, - 1 = I somewhat disagree, 0 = It's about fifty-fifty, I cannot decide, $1=$ I somewhat agree, 2 = I certainly agree). The respondents were also allowed to answer "I don't know, I have no opinion", but were asked to use it only when they had absolutely no information about the bank.

In Items 28 and 29, the respondents used a five-point scale with anchors of considerable experience $(=1)$ and no experience $(=5)$ to indicate the extent of their experience with the bank. In Item 30, they expressed their willingness to choose the bank in question if they were make an instant decision, and in Item 31 the degree of their willingness to recommend the particular bank to their friends. For their answers, they used a five-point scale where $1=$ certainly yes, $2=$ probably yes, 3 = I don't know, I cannot decide, $4=$ probably not, and $5=$ certainly not.

The questionnaire based on the semantic differential method consisted of a set of 42 sevenpoint scales. The anchors in each of the scales were bipolar adjectives or short statements, and respondents were asked to use them to describe the bank in question. The adjectives and statements were selected on the basis of a qualitative pilot study (using focus group). The characteristics selected for the method were those that respondents in the focus group applied spontaneously as classification criteria. Also included were characteristics in which a predominantly affective basis can be assumed.

\subsection{Sample}

In the research, a group of 199 respondents (109 men and 90 women) of different ages was used. Questionnaires were distributed by interviewers. The composition of the sample of respondents as regards the degree of their personal experience with individual banks is given in Tab.1.

Tab. 1 - Profile of the sample of respondents according to the degree of their personal experience with individual banks. Source: author.

\begin{tabular}{|l|c|c|c|c|c|c|}
\hline $\begin{array}{l}\text { Degree of personal } \\
\text { experience with the bank }\end{array}$ & $\begin{array}{c}\text { Substantial } \\
1\end{array}$ & 2 & 3 & 4 & None 5 & $\sum$ \\
\hline B1 & 44 & 53 & 36 & 38 & 28 & 199 \\
\hline B2 & 21 & 46 & 24 & 46 & 62 & 199 \\
\hline B3 & 9 & 13 & 7 & 30 & 138 & 197 \\
\hline B4 & 106 & 56 & 17 & 11 & 8 & 198 \\
\hline
\end{tabular}

\subsection{Analysis and results}

To find out the image content of individual banks investigated, means and standard deviations were calculated for each variable in questionnaires 1 and 2 . It was followed by a paired com- 
parison of individual banks. For each member of the pair, the statistical significance of differences between the means obtained when assessing individual banks was calculated. The results of paired comparison are not presented in their entirety here but merely referred to whenever necessary. A factor analysis was performed in both questionnaires in order to identify the image structure.

Analysis of the bank's image content and its comparison with the degree of willingness to choose the particular bank / with the degree of willingness to recommend the bank to one's friends

Image contents of individual banks are given in Tables 2 and 3.

Tab. 2 - Average scores (m) and standard deviations (SD) of individual items in individual banks - questionnaire 1. Source: author.

\begin{tabular}{|c|c|c|c|c|c|c|c|c|c|}
\hline \multirow{2}{*}{\multicolumn{2}{|c|}{ Questionnaire item }} & \multicolumn{2}{|c|}{ B1 } & \multicolumn{2}{|c|}{ B2 } & \multicolumn{2}{|c|}{ B3 } & \multicolumn{2}{|c|}{ B4 } \\
\hline & & \multirow{2}{*}{$\begin{array}{c}\mathrm{m} \\
0.63\end{array}$} & \multirow{2}{*}{$\begin{array}{l}\mathrm{SD} \\
1.02\end{array}$} & \multirow{2}{*}{$\frac{\mathrm{m}}{0.71}$} & \multirow{2}{*}{$\begin{array}{l}\mathrm{SD} \\
0.90\end{array}$} & \multirow{2}{*}{$\frac{\mathrm{m}}{0.52}$} & \multirow{2}{*}{$\begin{array}{l}\mathrm{SD} \\
0.96\end{array}$} & \multirow{2}{*}{$\begin{array}{c}\mathrm{m} \\
0.17\end{array}$} & \multirow{2}{*}{$\begin{array}{l}\mathrm{SD} \\
1.22\end{array}$} \\
\hline 1. & $\begin{array}{l}\text { It provides error-free serv- } \\
\text { ices }\end{array}$ & & & & & & & & \\
\hline 2. & $\begin{array}{l}\text { It provides progressive } \\
\text { services (payment via the } \\
\text { Internet, ...) }\end{array}$ & 0.92 & 0.88 & 0.83 & 0.91 & 1.39 & 0.86 & 0.09 & 1.24 \\
\hline 3. & It provides prompt services & 0.50 & 1.08 & 0.71 & 0.90 & 1.21 & 0.88 & -0.17 & 1.29 \\
\hline 4. & $\begin{array}{l}\text { It provides financial benefits } \\
\text { (good interest rates, ...) }\end{array}$ & -0.43 & 1.11 & 0.09 & 1.09 & 0.09 & 1.08 & -0.13 & 1.26 \\
\hline 5. & $\begin{array}{l}\text { It provides a wide range of } \\
\text { products/services }\end{array}$ & 0.85 & 0.97 & 0.79 & 1.01 & 0.54 & 1.04 & 0.63 & 1.09 \\
\hline 6. & $\begin{array}{l}\text { It provides some very good } \\
\text { products/services }\end{array}$ & 0.20 & 1.07 & 0.35 & 1.08 & 0.55 & 1.05 & 0.25 & 1.12 \\
\hline 7. & $\begin{array}{l}\text { It offers favourable entry } \\
\text { conditions (the required } \\
\text { amount of deposits, ...) }\end{array}$ & 0.18 & 1.08 & 0.19 & 1.07 & 0.16 & 0.99 & 0.50 & 1.10 \\
\hline 8. & $\begin{array}{l}\text { The fees charged for its } \\
\text { services are reasonable }\end{array}$ & -0.19 & 1.17 & -0.02 & 1.15 & -0.12 & 1.16 & -0.20 & 1.30 \\
\hline 9. & $\begin{array}{l}\text { It has convenient opening } \\
\text { hours }\end{array}$ & 0.96 & 1.08 & 0.77 & 1.04 & 0.86 & 1.15 & 0.46 & 1.37 \\
\hline 10. & It has its own ATMs & 1.44 & 0.86 & 0.88 & 1.13 & -0.39 & 1.32 & 1.66 & 0.66 \\
\hline 11. & $\begin{array}{l}\text { Its employees are fully } \\
\text { competent }\end{array}$ & 0.79 & 0.94 & 0.74 & 0.88 & 0.65 & 0.92 & 0.53 & 1.17 \\
\hline 12. & Its management is competent & 0.05 & 1.12 & 0.64 & 0.96 & 0.59 & 1.08 & 0.12 & 1.10 \\
\hline 13. & $\begin{array}{l}\text { Its branches are conveniently } \\
\text { located (it is accessible, ...) }\end{array}$ & 1.02 & 1.00 & 0.35 & 1.22 & 0.01 & 1.35 & 1.29 & 0.99 \\
\hline 14. & $\begin{array}{l}\text { It has a good internal organi- } \\
\text { sation }\end{array}$ & 0.17 & 1.02 & 0.36 & 1.93 & 0.35 & 1.00 & 0.04 & 1.03 \\
\hline
\end{tabular}




\begin{tabular}{|c|c|c|c|c|c|c|c|c|c|}
\hline 15. & It is well promoted & 0.85 & 0.99 & 0.61 & 1.08 & 0.06 & 1.37 & 0.75 & 1.09 \\
\hline 16. & It sponsors the right causes & 0.18 & 1.07 & 0.16 & 1.01 & -0.32 & 1.00 & 0.49 & 0.99 \\
\hline 17. & $\begin{array}{l}\text { It is well "guaranteed" by the } \\
\text { state (the state will not allow } \\
\text { it to go bankrupt) }\end{array}$ & 0.98 & 1.02 & 0.58 & 1.19 & -0.75 & 1.27 & 1.08 & 1.14 \\
\hline 18. & $\begin{array}{l}\text { It provides open information } \\
\text { (about its business, ...) }\end{array}$ & -0.17 & 1.19 & -0.02 & 1.05 & -0.36 & 1.02 & 0.00 & 1.11 \\
\hline 19. & $\begin{array}{l}\text { It provides a pleasant envi- } \\
\text { ronment for its clients }\end{array}$ & 1.09 & 0.89 & 0.97 & 0.86 & 0.85 & 0.92 & 0.75 & 1.13 \\
\hline 20. & It appreciates its clients & 0.38 & 1.16 & 0.76 & 0.89 & 0.73 & 0.87 & 0.22 & 1.27 \\
\hline 21. & $\begin{array}{l}\text { The bank's employees are } \\
\text { able to provide comprehen- } \\
\text { sible and complete informa- } \\
\text { tion }\end{array}$ & 0.65 & 1.05 & 0.80 & 0.85 & 0.65 & 0.92 & 0.45 & 1.20 \\
\hline 22. & $\begin{array}{l}\text { The bank's employees are } \\
\text { friendly and helpful }\end{array}$ & 0.66 & 1.04 & 0.82 & 0.87 & 0.59 & 0.98 & 0.46 & 1.29 \\
\hline 23. & $\begin{array}{l}\text { The bank's employees know } \\
\text { their clients }\end{array}$ & -0.10 & 1.19 & 0.10 & 1.08 & -0.14 & 1.17 & -0.11 & 1.23 \\
\hline 24. & $\begin{array}{l}\text { The bank's employees under- } \\
\text { stand their clients' needs }\end{array}$ & 0.26 & 1.09 & 0.35 & 0.96 & 0.41 & 0.99 & 0.27 & 1.19 \\
\hline 25. & $\begin{array}{l}\text { The bank's employees are } \\
\text { active towards the clients } \\
\text { (informing them, volunteer- } \\
\text { ing information) }\end{array}$ & 0.33 & 1.12 & 0.51 & 1.02 & 0.39 & 1.07 & 0.25 & 1.32 \\
\hline 26. & $\begin{array}{l}\text { The bank's employees are } \\
\text { pleasant and smile }\end{array}$ & 0.53 & 1.12 & 0.71 & 0.97 & 0.45 & 1.14 & 0.44 & 1.24 \\
\hline 27. & $\begin{array}{l}\text { The bank's employees have } \\
\text { an individual approach to } \\
\text { their clients }\end{array}$ & 0.16 & 1.21 & 0.38 & 1.03 & 0.26 & 1.16 & 0.09 & 1.27 \\
\hline
\end{tabular}

Tab. 3 - Average scores (m) and standard deviations (SD) of individual items in the semantic differential method. Source: author.

\begin{tabular}{|l|l|c|c|c|c|c|c|c|c|}
\hline \multirow{2}{*}{ Questionnaire item } & \multicolumn{2}{|c|}{ Bank 1 } & \multicolumn{2}{c|}{ Bank 2 } & \multicolumn{2}{c|}{ Bank 3 } & \multicolumn{2}{c|}{ Bank 4 } \\
\cline { 3 - 10 } & $\mathrm{m}$ & $\mathrm{SD}$ & $\mathrm{m}$ & $\mathrm{SD}$ & $\mathrm{m}$ & $\mathrm{SD}$ & $\mathrm{m}$ & SD \\
\hline 32. & unproblematic - problematic & 3.63 & 1.60 & 3.24 & 1.53 & 3.45 & 1.40 & 3.74 & 1.79 \\
\hline 33. & ordinary - original & 2.79 & 1.43 & 3.51 & 1.47 & 5.62 & 1.65 & 2.22 & 1.33 \\
\hline 34. & clean - dirty & 3.01 & 1.65 & 2.98 & 1.43 & 3.12 & 1.41 & 3.23 & 1.68 \\
\hline 35. & go-getting - not go-getting & 3.74 & 1.53 & 3.16 & 1.51 & 3.10 & 1.75 & 4.53 & 1.63 \\
\hline 36. & unattractive - attractive & 4.62 & 1.45 & 4.86 & 1.27 & 4.98 & 1.64 & 4.04 & 1.63 \\
\hline 37. & poor - rich & 5.05 & 1.39 & 5.34 & 1.16 & 4.16 & 1.34 & 4.94 & 1.36 \\
\hline 38. & untrustworthy - trustworthy & 4.84 & 1.48 & 4.99 & 1.36 & 4.30 & 1.43 & 4.88 & 1.56 \\
\hline
\end{tabular}




\begin{tabular}{|c|c|c|c|c|c|c|c|c|c|}
\hline 39. & $\begin{array}{l}\text { financially affordable - finan- } \\
\text { cially unaffordable }\end{array}$ & 3.12 & 1.42 & 3.23 & 1.41 & 3.68 & 1.32 & 2.48 & 1.23 \\
\hline 40. & $\begin{array}{l}\text { not financially beneficial - fi- } \\
\text { nancially beneficial }\end{array}$ & 4.19 & 1.45 & 4.58 & 1.30 & 4.28 & 1.29 & 4.40 & 1.49 \\
\hline 41. & uneconomical - economical & 3.84 & 1.62 & 4.72 & 1.18 & 4.46 & 1.14 & 4.08 & 1.56 \\
\hline 42. & dark-clear & 4.37 & 1.59 & 4.65 & 1.48 & 4.21 & 1.71 & 4.36 & 1.58 \\
\hline 43. & new - traditional & 5.24 & 1.64 & 4.65 & 1.74 & 1.80 & 1.15 & 6.08 & 1.30 \\
\hline 44. & $\begin{array}{l}\text { personally close to me - per- } \\
\text { sonally distant to me }\end{array}$ & 3.81 & 1.84 & 4.23 & 1.87 & 4.97 & 1.94 & 3.14 & 1.81 \\
\hline 45. & resistant - fragile & 3.07 & 1.32 & 3.01 & 1.28 & 4.24 & 1.46 & 2.92 & 1.30 \\
\hline 46. & $\begin{array}{l}\text { not having a positive per- } \\
\text { spective - having a positive } \\
\text { perspective }\end{array}$ & 5.08 & 1.40 & 5.37 & 1.20 & 5.40 & 1.54 & 4.66 & 1.62 \\
\hline 47. & progressive - conservative & 4.12 & 1.59 & 3.48 & 1.50 & 2.43 & 1.42 & 4.80 & 1.67 \\
\hline 48. & $\begin{array}{l}\text { failing to correspond to my } \\
\text { needs - corresponding to my } \\
\text { needs }\end{array}$ & 4.29 & 1.86 & 4.30 & 1.66 & 3.64 & 1.87 & 4.43 & 1.95 \\
\hline 49. & $\begin{array}{l}\text { connected with scandals } \\
\text { - without scandals }\end{array}$ & 3.39 & 1.72 & 4.16 & 1.60 & 5.29 & 1.44 & 3.99 & 1.72 \\
\hline 50. & immodest - modest & 3.18 & 1.35 & 3.65 & 1.41 & 4.01 & 1.52 & 4.00 & 1.53 \\
\hline 51. & flexible-inflexible & 3.58 & 1.57 & 3.26 & 1.26 & 2.62 & 1.33 & 4.26 & 1.60 \\
\hline 52. & $\begin{array}{l}\text { with a good reputation }- \text { with a } \\
\text { bad reputation }\end{array}$ & 3.57 & 1.54 & 3.23 & 1.40 & 3.19 & 1.20 & 3.48 & 1.53 \\
\hline 53. & strong - weak & 2.78 & 1.23 & 2.64 & 1.15 & 3.83 & 1.42 & 2.98 & 1.38 \\
\hline 54. & $\begin{array}{l}\text { with agreeable clients - with } \\
\text { disagreeable clients }\end{array}$ & 3.35 & 1.19 & 3.54 & 1.17 & 3.54 & 1.21 & 3.36 & 1.38 \\
\hline 55. & $\begin{array}{l}\text { with an unstable position in the } \\
\text { market - with a stable position } \\
\text { in the market }\end{array}$ & 5.14 & 1.41 & 5.21 & 1.39 & 3.98 & 1.32 & 5.29 & 1.46 \\
\hline 56. & $\begin{array}{l}\text { with a wide range of products } \\
\text { on offer - with a narrow range } \\
\text { of products on offer }\end{array}$ & 2.95 & 1.38 & 2.80 & 1.09 & 3.52 & 1.43 & 3.10 & 1.53 \\
\hline 57. & $\begin{array}{l}\text { with a large number of branch- } \\
\text { es - with a small number of } \\
\text { branches }\end{array}$ & 2.45 & 1.27 & 3.70 & 1.69 & 5.22 & 1.70 & 1.65 & 1.01 \\
\hline 58. & $\begin{array}{l}\text { with bad economic results } \\
\text { - with good economic results }\end{array}$ & 4.19 & 1.58 & 4.82 & 1.20 & 4.31 & 1.15 & 4.39 & 1.52 \\
\hline 59. & $\begin{array}{l}\text { with bad client care - with } \\
\text { good client care }\end{array}$ & 4.76 & 1.50 & 5.01 & 1.10 & 4.89 & 1.12 & 4.52 & 1.67 \\
\hline 60. & reliable - unreliable & 3.17 & 1.41 & 2.89 & 1.17 & 3.49 & 1.27 & 3.15 & 1.54 \\
\hline 61. & agreeable - disagreeable & 3.29 & 1.59 & 3.11 & 1.48 & 3.25 & 1.58 & 3.58 & 1.73 \\
\hline 62. & stable - unstable & 3.02 & 1.41 & 2.93 & 1.30 & 3.89 & 1.44 & 2.86 & 1.43 \\
\hline
\end{tabular}




\begin{tabular}{|l|l|c|c|c|c|c|c|c|c|}
\hline 63. & $\begin{array}{l}\text { with a low quality of serv- } \\
\text { ices - with a high quality of } \\
\text { services }\end{array}$ & 4.95 & 1.25 & 5.04 & 1.12 & 4.88 & 1.264 & 4.48 & 1.57 \\
\hline 64. & fat - slim & 3.18 & 1.42 & 3.60 & 1.39 & 5.01 & 1.33 & 2.98 & 1.43 \\
\hline 65. & unsuccessful - successful & 4.86 & 1.34 & 5.22 & 1.17 & 4.74 & 1.24 & 4.94 & 1.33 \\
\hline 66. & small - big & 5.95 & 0.90 & 5.59 & 1.18 & 3.24 & 1.44 & 6.12 & 1.07 \\
\hline 67. & $\begin{array}{l}\text { proactive towards clients - not } \\
\text { proactive towards clients }\end{array}$ & 3.31 & 1.50 & 3.04 & 1.15 & 3.25 & 1.27 & 3.48 & 1.73 \\
\hline 68. & sought after - not sought after & 2.86 & 1.25 & 3.11 & 1.32 & 4.17 & 1.55 & 2.52 & 1.29 \\
\hline 69. & anonymous - distinct & 5.37 & 1.20 & 5.15 & 1.33 & 4.11 & 1.73 & 5.02 & 1.49 \\
\hline 70. & $\begin{array}{l}\text { for families and private } \\
\text { persons - for managers and } \\
\text { entrepreneurs }\end{array}$ & 5.23 & 1.43 & 4.75 & 1.60 & 5.13 & 1.42 & 1.98 & 1.07 \\
\hline 71. & unknown - known & 6.34 & 0.94 & 5.92 & 1.17 & 3.65 & 1.78 & 6.56 & 0.79 \\
\hline 72. & responsible - irresponsible & 3.15 & 1.42 & 3.01 & 1.222 & 3.41 & 1.08 & 3.11 & 1.45 \\
\hline 73. & healthy - unhealthy & 3.58 & 1.59 & 2.97 & 1.17 & 3.32 & 1.28 & 3.37 & 1.55 \\
\hline
\end{tabular}

Note: The positive and negative poles of the SD scales are arranged randomly, i.e. they do not have the same directions.

The degree of willingness of respondents to use a particular bank if they were to choose now and recommend it to their friends is given in Table 4.

Tab. 4 - Willingness to use a bank / recommend a bank to one's friends. Source: author.

\begin{tabular}{|l|l|c|c|c|c|c|c|c|c|}
\hline \multirow{2}{*}{ Questionnaire item } & \multicolumn{2}{|c|}{ Bank 1 } & \multicolumn{2}{c|}{ Bank 2 } & \multicolumn{2}{c|}{ Bank 3 } & \multicolumn{2}{c|}{ Bank 4 } \\
\cline { 2 - 10 } & $\mathrm{m}$ & $\mathrm{SD}$ & $\mathrm{m}$ & $\mathrm{SD}$ & $\mathrm{m}$ & $\mathrm{SD}$ & $\mathrm{m}$ & $\mathrm{SD}$ \\
\hline 1. & $\begin{array}{l}\text { If I were deciding now, I would } \\
\text { choose this bank }\end{array}$ & 2.77 & 1.19 & 2.71 & 1.08 & 3.27 & 1.14 & 2.70 & 1.36 \\
\hline 2. & $\begin{array}{l}\text { I would recommend this bank to } \\
\text { my friends }\end{array}$ & 2.80 & 1.19 & 2.70 & 1.06 & 3.26 & 1.11 & 2.70 & 1.31 \\
\hline
\end{tabular}

Note: scale $1-5$, where 1 = certainly yes, 2 = probably yes, $3=$ I don't know, I cannot decide, 4 = probably not, $5=$ certainly not $; \quad \mathrm{m}=$ mean, $\mathrm{SD}=$ standard deviation

An analysis showed that the image content differed from one investigated bank to another. The answers indicated that most positive overall image was enjoyed by the B2 bank. The respondents view it as the strongest, the most trustworthy and the most successful of the banks investigated, and its particularly strong point is the quality of services. The B4 is considered a well-known and stable bank, materially well-provided for (with a large number of branches, many ATMs), but also a bank with the poorest quality of services, both from the technological and human resources points of view (the quality of its services is considered the worst of all the banks investigated, and the difference is, as the paired comparison showed, statistically significant). From the quality of services point of view, the B4's image is thus worse than the image of any other bank investigated. The B1 bank was positively evaluated by the respondents from the functional 
point of view (which included the range of services, opening hours, etc.), but compared with the others, they considered it not very financially advantageous, with not as good reputation as the other banks have, and a rather poor financial performance. The B3 bank is considered by the respondents as a bank with good prospects, which provides prompt services, and as a progressive bank that enjoys good reputation. The significant difference in the image content between this bank and the rest of the banks is that respondents view it as a less stable, less trustworthy and less resistant bank, and as a bank that least corresponds to their needs.

As indicated in Table 4, the highest (and practically the same) degrees of willingness to choose a particular bank and recommend it to friends were shared by the B2 and B4 banks (if, however, we compare the sizes of the standard deviation, we see that the respondents' opinions were more consistent in the case of the B2 bank). The B1 bank showed only a slightly lower value, but the B3 value is markedly lower than that of any other of the banks investigated (the difference between the B3 and all the other banks is significant at the 0.01 level). Similar trends were demonstrated by the degrees of willingness to recommend individual banks to one's friends.

A comparison between image contents of individual banks and the degree of willingness to recommend the bank to one's friends shows that the B2 and B4 banks exhibit approximately the same levels of the willingness of the respondents to recommend the bank to their friends although image contents of the two banks are clearly different. While the B2 bank is perceived as a strong, trustworthy and successful bank, whose quality of services is a particularly strong point, the B4 is considered a well-known and stable bank, well provided for from the material point of view, but a bank with a rather poor quality of services. In spite of it, that particular bank meets the respondents' needs best, and is personally closest to them. Compared with the B2 and B4 banks, the willingness to choose and recommend the B1 bank is only slightly lower. The willingness of respondents to choose and recommend the $\mathrm{B} 3 \mathrm{bank}$, whose strong point was the positive perception of its good prospects, speed of services, progressiveness and good reputation, was, however, significantly lower. It is the bank which is the least trustworthy for the respondents and is viewed as the bank the least corresponding to their needs.

A comparison between the image contents of individual banks and the willingness to choose or recommend them indicates that different components in the image content have probably different weights in decision-making processes and in customer loyalty. The hypothesis about different impacts of image components published in the literature (see Bloemer, De Ruyter \& Peeters, 1998) seems to be supported.

\section{Image structure analysis}

A factor analysis was used to process the data obtained from the two questionnaires administered to identify image components of individual banks in relation to conative (behavioural) tendencies of the respondents. Data were processed for each bank separately and the results are shown in Tables $5-8$. The content of each factor is described by means of item loadings in the order of loading sizes. Only loadings greater than 0.5 are listed for cognitive and affective items, and loadings greater than 0.4 for conative items.

It follows from Table 5 that the willingness to choose and recommend the B1 bank is linked with Factor 1, which we called, in accordance with the most strong item loadings, trustworthiness / 
stability / congeniality. The congeniality of B1, as indicated by the content of the first factor, is related to the financial advantageousness and modesty.

In the case of the B2 bank (see Table 6), the willingness to choose and recommend this bank is more closely related with the following image content components: 1 . facilities, financial conditions and product range, 2. bank dynamism (for those who were willing to choose and recommend the bank to their friends, dynamism is what makes the bank agreeable and corresponds to their needs), 3. stability / trustworthiness / congeniality. In this case, the stability, trustworthiness and congeniality of the bank were related to its resistance, strength, wealth, big size and renown.

Tab. 5 - Bank 1: A description of the content of the extracted factors (a list of items and their polarities). Source: author.

\begin{tabular}{|c|c|c|}
\hline Factor & cognitive and affective items & conative items \\
\hline 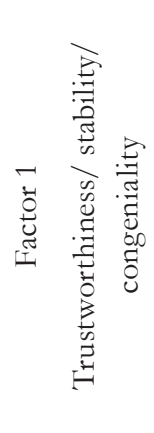 & $\begin{array}{l}0,793 \text { economical, }-0,748 \text { with a good reputation, }-0,742 \\
\text { reliable, } 0,715 \text { trustworthy, }-0,709 \text { healthy, } 0,691 \text { with } \\
\text { good economic results, }-0,688 \text { agreeable, }-0,686 \text { with } \\
\text { a stable position in the market, } \mathbf{0 , 6 7 6} \text { corresponding } \\
\text { to my needs, }-0,671 \text { stable, }-0,664 \text { unproblematic, } \\
0,652 \text { successful, } 0,632 \text { without scandals, } 0,622 \text { having } \\
\text { a positive perspective, - } 0,607 \text { responsible, } 0,595 \text { clear, } \\
0,584 \text { financially beneficial, }-0,554 \text { strong, }-\mathbf{- 0 , 5 4 8} \\
\text { personally close to me, }-0,541 \text { with agreeable clients, } \\
0,536 \text { attractive, } 0,534 \text { with good client care }\end{array}$ & $\begin{array}{l}-0,636 \\
\text { If I were decid- } \\
\text { ing now, I would } \\
\text { choose this bank, } \\
-0,589 \\
\text { I would recom- } \\
\text { mend this bank } \\
\text { to my friends }\end{array}$ \\
\hline 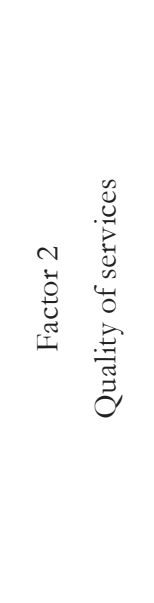 & $\begin{array}{l}0,776 \text { the bank's employees are able to provide } \\
\text { comprehensible and complete information, } 0,737 \text { the } \\
\text { bank's employees are active towards the clients, } 0,721 \text { the } \\
\text { bank's employees understand their clients' needs, } 0,717 \\
\text { the bank's employees are friendly and helpful, } 0,705 \text { the } \\
\text { bank's employees have an individual approach to their } \\
\text { clients, } 0,687 \text { the bank's employees are pleasant and they } \\
\text { smile, 0,666 the bank's employees are fully competent, } \\
0,663 \text { the bank's employees know their clients, } 0,650 \\
\text { the bank appreciates its clients, } 0,574 \text { the bank has } \\
\text { convenient opening hours, } 0,553 \text { the bank provides } \\
\text { a pleasant environment to its clients, } 0,549 \text { the bank } \\
\text { provides prompt services, } 0,500 \text { the bank has a good } \\
\text { internal organisation }\end{array}$ & \\
\hline 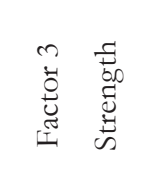 & $\begin{array}{l}0,624 \text { big, } 0,619 \text { distinct, } 0,618 \text { known, }-0,546 \text { strong, } \\
-0,517 \text { with a wide range of products on offer, }-0,506 \\
\text { stable, } \\
-0,502 \text { fat }\end{array}$ & \\
\hline
\end{tabular}




\begin{tabular}{|c|c|c|}
\hline 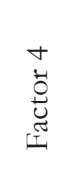 & 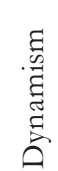 & $\begin{array}{l}0,660 \text { original, }-0,639 \text { new, }-0,557 \text { progressive, }-0,527 \\
\text { go-getting }\end{array}$ \\
\hline
\end{tabular}

Tab. 6 - Bank 2: A description of the content of the extracted factors. Source: author.

\begin{tabular}{|c|c|c|}
\hline Factor & cognitive and affective items & conative items \\
\hline 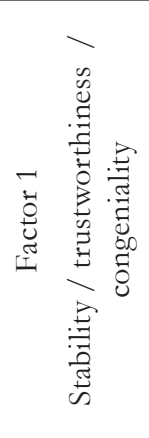 & $\begin{array}{l}-0,815 \text { stable, } 0,782 \text { having a positive perspective, }-0,760 \\
\text { resistant, - } 0,734 \text { healthy, }-0,730 \text { responsible, - } 0,714 \text { with } \\
\text { a good reputation, } 0,707 \text { trustworthy, } 0,710 \text { successful, } \\
-0,684 \text { agreeable, }-0,678 \text { unproblematic, } 0,663 \text { with good } \\
\text { economic results, - 0,651 sought after, 0,634 rich, -0,633 } \\
\text { strong, 0,630 with a high quality of services, 0,629 at- } \\
\text { tractive, 0,621 with a stable position in the market, -0,613 } \\
\text { reliable, } 0,610 \text { clear, }-0,556 \text { proactive towards clients, } \\
0,553 \text { economical, } 0,520 \text { big, }-0,519 \text { clean, }-0,509 \text { with a } \\
\text { wide range of products on offer, } 0,506 \text { without scandals }\end{array}$ & $\begin{array}{l}-0,408 \\
\text { If I were deciding } \\
\text { now, I would } \\
\text { choose this bank }\end{array}$ \\
\hline 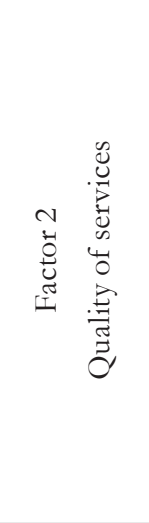 & $\begin{array}{l}0,716 \text { the bank's employees are able to provide } \\
\text { comprehensible and complete information, 0,675 the } \\
\text { bank's employees understand their clients' needs, 0,668 } \\
\text { the bank's employees have an individual approach to } \\
\text { their clients, 0,650 the bank's employees are pleasant } \\
\text { and they smile, 0,624 the bank's employees are active } \\
\text { towards the clients, 0,600 the bank's employees are fully } \\
\text { competent, 0,610 the bank's employees know their } \\
\text { clients, 0,561 the bank appreciates its clients, } 0,544 \\
\text { the bank's management is competent, } 0,519 \text { the bank } \\
\text { provides a pleasant environment for its clients, } 0,505 \text { the } \\
\text { bank has a good internal organisation }\end{array}$ & \\
\hline 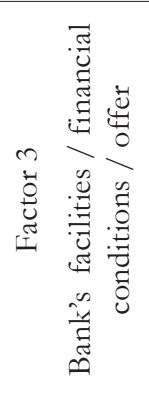 & $\begin{array}{l}-0,652 \text { the bank with a large number of branches, } \\
0,648 \text { its branches are conveniently located, } 0,616 \text { it has } \\
\text { convenient opening hours, } 0,570 \text { financially beneficial, } \\
-0,560 \text { financially affordable, } 0,554 \text { it offers favour- } \\
\text { able entry conditions, 0,545 the fees charged for its } \\
\text { services are reasonable, 0,544 it provides a wide range } \\
\text { of products/services, 0,516 it has its own ATMs, 0,512 it } \\
\text { provides some very good products/services }\end{array}$ & $\begin{array}{l}-0,454 \\
\text { If I were decid- } \\
\text { ing now, I would } \\
\text { choose this bank, } \\
-0,437 \\
\text { I would recom- } \\
\text { mend this bank } \\
\text { to my friends }\end{array}$ \\
\hline
\end{tabular}




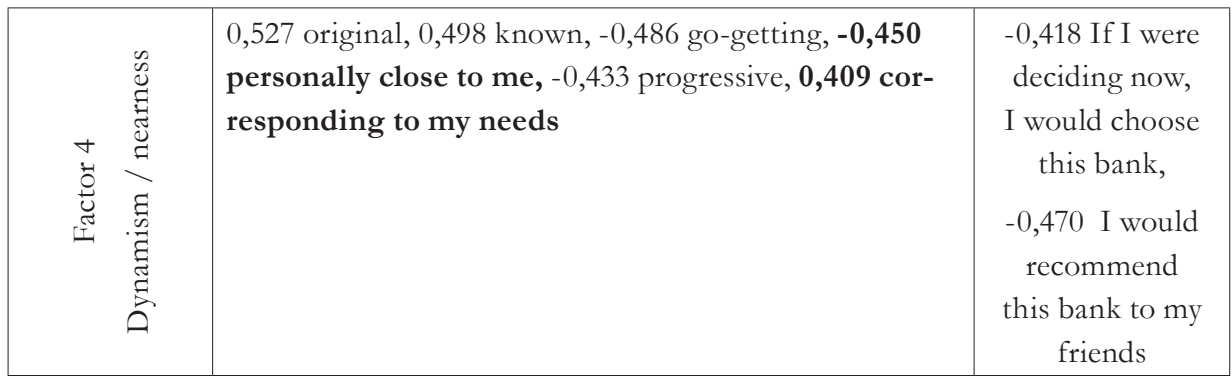

Tab. 7 - Bank 3: A description of the content of the extracted factors. Source: author.

\begin{tabular}{|c|c|c|}
\hline Factor & cognitive and affective items & conative items \\
\hline 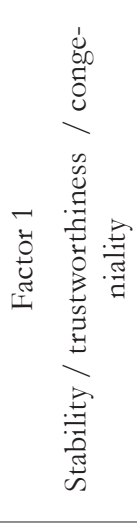 & $\begin{array}{l}\mathbf{0 , 7 9 0} \text { corresponding to my needs, }-0,727 \text { agreeable, } \\
0,724 \text { successful, }-0,723 \text { stable, } 0,702 \text { trustworthy, }-0,698 \\
\text { reliable, } 0,697 \text { with good client care, }-0,692 \text { healthy, } 0,674 \\
\text { with a high quality of services, } 0,662 \text { having a positive } \\
\text { perspective, - }-0,657 \text { proactive towards clients, }-0,642 \\
\text { with a good reputation, } 0,636 \text { without scandals, } 0,635 \\
\text { with good economic results, }-0,616 \text { with agreeable clients, } \\
\text { - 0,611 sought after, } \mathbf{0 , 6 1 0} \text { personally close to me,- } \\
\text { 0,608 unproblematic, } 0,600 \text { financially beneficial, }-0,594 \\
\text { progressive, - }-0,592 \text { responsible, } 0,575 \text { attractive, } 0,575 \\
\text { with a stable position in the market, } 0,567 \text { clear, } 0,534 \\
\text { economical, }-0,523 \text { strong, }-0,508 \text { resistant, }-0,507 \text { flexible }\end{array}$ & $\begin{array}{l}-0,677 \\
\text { If I were decid- } \\
\text { ing now, I would } \\
\text { choose this bank, } \\
-0,656 \\
\text { I would recom- } \\
\text { mend this bank } \\
\text { to my friends }\end{array}$ \\
\hline 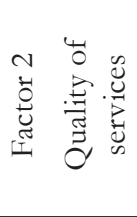 & $\begin{array}{l}0,717 \text { distinct, } 0,664 \text { known, } 0,633 \text { big, } 0,616 \text { it is well } \\
\text { promoted, } 0,610 \text { rich, } 0,606 \text { it sponsors the right causes, } \\
-0,597 \text { resistant, } 0,584 \text { it provides a wide range of products/ } \\
\text { services, }-0,580 \text { strong, } 0,559 \text { with a stable position in the } \\
\text { market, } 0,534 \text { it provides financial benefits }\end{array}$ & \\
\hline 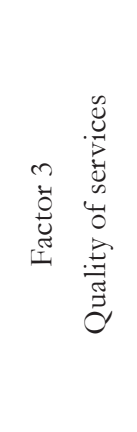 & $\begin{array}{l}0,733 \text { the bank's employees know their clients, } 0,708 \text { the } \\
\text { bank's employees understand their clients' needs, } 0,680 \\
\text { the bank's employees have an individual approach to their } \\
\text { clients, } 0,658 \text { the bank's employees are able to provide } \\
\text { comprehensible and complete information, } 0,656 \text { the } \\
\text { bank appreciates its clients, } 0,650 \text { the bank's employees } \\
\text { are friendly and helpful, 0,646 the bank's employees are } \\
\text { pleasant and they smile, } 0,621 \text { the bank's employees } \\
\text { are active towards the clients, } 0,513 \text { the bank provides a } \\
\text { pleasant environment to their clients }\end{array}$ & \\
\hline
\end{tabular}






In the B3 bank, the willingness to choose and recommend is related to the congeniality, stability and trustworthiness of the bank. Positive feelings towards a bank (and the willingness to choose it) were very closely connected to the degree with which the bank meets the respondent's needs and, which was characteristic for this particular bank, to the bank's progressive character.

Tab. 8 - Bank 4: A description of the content of the extracted factors. Source: author.

\begin{tabular}{|c|c|c|}
\hline Factor & cognitive and affective items & conative items \\
\hline 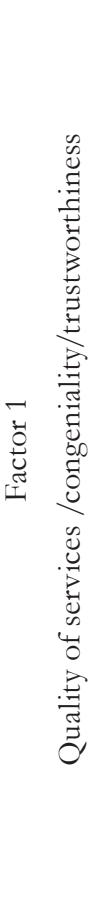 & 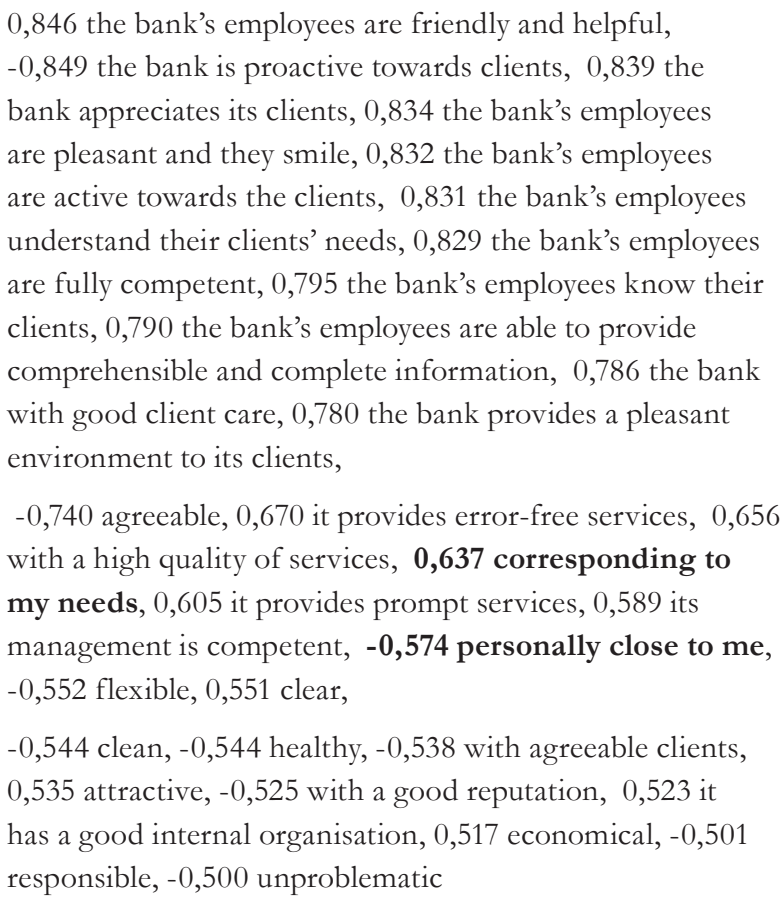 & $\begin{array}{l}-0,655 \\
\text { If I were } \\
\text { deciding now, } \\
\text { I would choose } \\
\text { this bank, } \\
-0,657 \\
\text { I would } \\
\text { recommend } \\
\text { this bank to my } \\
\text { friends }\end{array}$ \\
\hline
\end{tabular}




\begin{tabular}{|c|c|c|}
\hline 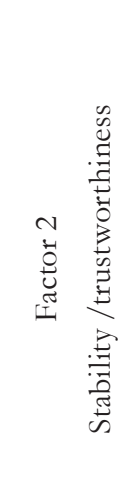 & $\begin{array}{l}-0,814 \text { strong, }-0,745 \text { stable, }-0,723 \text { reliable, }-0,657 \text { with a } \\
\text { good reputation, } 0,692 \text { trustworthy, } 0,671 \text { rich, } 0,689 \text { having } \\
\text { a positive perspective, } 0,632 \text { with a stable position in the } \\
\text { market, 0,633 successful, }-0,630 \text { unproblematic, } 0,608 \text { with } \\
\text { good economic results, }-0,601 \text { healthy, }-0,596 \text { resistant, } 0,588 \\
\text { attractive, }-0,550 \text { clean, } 0,540 \text { corresponding to my needs, } \\
\text { 0,538 economical, } 0,533 \text { clear, - 0,518 with a good reputation, } \\
-0,515 \text { with a wide range of products on offer, 0,509 without } \\
\text { scandals, }-0,507 \text { responsible, } 0,504 \text { with a high quality of } \\
\text { services, }-0,496 \text { agreeable }\end{array}$ & $\begin{array}{l}-0,447 \\
\text { If I were } \\
\text { deciding now, } \\
\text { I would choose } \\
\text { this bank, } \\
-0,446 \\
\text { I would } \\
\text { recommend } \\
\text { this bank to my } \\
\text { friends }\end{array}$ \\
\hline 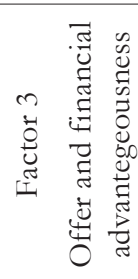 & $\begin{array}{l}0,677 \text { it provides favourable entry conditions, } 0,660 \text { it } \\
\text { provides financial benefits, } 0,651 \text { the fees charged for its } \\
\text { services are reasonable, } 0,563 \text { it provides some very good } \\
\text { products/services, } 0,525 \text { it provides open information (about } \\
\text { its business ...) }\end{array}$ & \\
\hline 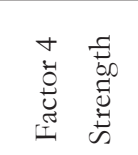 & $\begin{array}{l}\text { 0,672 with a large number of branches, }-0,670 \text { big, }-0,588 \\
\text { new, }-0,659 \text { known, } 0,614 \text { the bank for managers and } \\
\text { entrepreneurs }\end{array}$ & \\
\hline
\end{tabular}

In the B4 bank, the willingness to choose and recommend it to friends is most closely related, as indicated by Factor 1, to the bank's staff, who are friendly, helpful and active, know their customers and understand their problems. These characteristics correspond to the respondents' needs, and determine their feelings of the bank's proximity. The human dimension of the quality of services and the bank's nearness to respondents explain why the bank is viewed as congenial and attractive and evaluated as responsible, economic, reliable and trustworthy.

In B4, the willingness to choose and recommend this bank is somewhat less related to the bank's stability and trustworthiness, which is also connected with some other aspects of the quality of services (speed of services, convenient opening hours).

\section{CONCLUSIONS}

Based on the research results, we can formulate the following conclusions:

- Descriptions of the contents of individual factors extracted by means of factor analysis in individual banks suggest that the image structures of individual banks in the respondents' minds are not homogeneous, although there is a degree of similarity among them. There are basically two types of contents of factors identified in image structures of individual banks: contents predominantly emotional and evaluative in character (e.g. trustworthiness, congeniality), and contents of cognitive or combined cognitive and evaluative character, which 
are related to the bank's behaviour in the market and to the functional aspects of the bank (bank's dynamism, its strength, quality of services, offer, financial advantageousness). In these, a more rational basis may be assumed.

- Different components in the image content have different weights in decision-making processes and in customer loyalty. A comparison between image contents of individual banks and the degree of willingness to choose the bank and to recommend the bank to one's friends shows that some banks exhibit approximately the same levels of the willingness of respondents to choose and recommend them although the image contents concerning quality of services are clearly different.

- The content of Factor 1 is similar in banks B1, B2 and B3, and includes trustworthiness, stability and congeniality. In the B4 bank, Factor 1 includes human aspects of services in combination with congeniality and trustworthiness, while stability and trustworthiness are separately included in Factor 2. This means that in B4 the components referring to quality are clearly linked to an affective relationship with the bank. This assumption is corroborated by the fact that the factor in B4 includes also items "I find the bank agreeable" and "personally close to me". These items are not included in the "quality of services" factors of the other banks. The respondents' relationship to the B4 bank seems therefore to be based on their personal contacts with bank employees and their perception of B4 as "their bank". This may explain why respondents were willing to choose the bank and recommend it to their friends as frequently as the B2 bank (characterized by the best quality of its services) although the quality of its services was evaluated significantly worse than that of any of the other banks investigated.

- Results of the research indicate that the general meanings dimensions identified by Osgood (1957), i.e. "good - bad" (gives rise to the structural component of the bank's trustworthiness / stability / congeniality), "strong - weak" (the bank's strength) and "active - passive" (the bank's dynamism), probably play a role in creating the content of corporate image of each bank. What was considered good or bad, congenial or not congenial in banks (i.e. evaluation criteria) by the respondents in our study, seems to be related not only to general aspects of evaluation, but also to respondents' needs.

- Conative items of all the banks were included in factors that were the result of evaluation in the "good - bad" dimension, i.e. conative items in B1 are included in the factor "trustworthiness / stability / congeniality", in B2 in the factor "stability / trustworthiness/congeniality", in B3 in "congeniality / stability / trustworthiness", and in B4 in Factor 1 ("quality of service/congeniality/trustworthiness") and Factor ("stability / trustworthiness"). This means that the willingness to choose and recommend a bank was always linked with the trustworthiness, stability and congeniality of the bank. In some of the banks, conative items are included also in some other factors, which depend on the character of the respondents' relationship with individual banks.

There are very few research studies focusing on the identification of bank image dimensions. Comparing the bank dimensions identified in our study with results of the few studies that have been published, we can see they are in high agreement. The dimension of trustworthiness / sta- 
bility / congeniality corresponds to the dimension of stability/credibility identified by Van Heerden and Puth (1995) and the dimension of security identified by Flavian et al. (2005, in Bravo, Montaner \& Pina, 2009). In agreement with the results of Van Heerden and Puth, the dimension of dynamism was identified; in correspondence with both of the above mentioned studies, we identified the dimension of quality of services. The authors use slightly different names for the last mentioned dimension, but its content is the same.

Summarizing the results of the study presented they seem to indicate that the sources of similarity in the structure of the bank's reflection in the respondents' mind are universal connotative dimensions identified by Osgood (1957), i.e. "good - bad", "strength", "activity" together with functional areas of banks evaluations, and the sources of differences are mainly different characters of the respondents' relationships to individual banks. In all the banks, the willingness to choose the bank and recommend it to friends is always linked to the bank's evaluation in the "good - bad" dimension. Of other components of image as the reflection in the respondents" mind, the willingness to choose and recommend banks is linked to slightly different image content items, which seem to be primarily linked to the respondents' needs.

\section{PRACTICAL IMPLICATIONS}

The practical implications of the research results are two-fold: in relation to image assessment and interpretation of results, and in relation to marketing practice in banks.

The research has revealed that the relation of consumers towards certain banks may be more significantly determined by rational (cognitive) factors, while emotional factors play the decisive role in the case of other banks. An analysis concentrating, e.g. only on opinions on individual banks and disregarding the character of the respondents' relationships towards the banks, creates the risk that the results of the bank image analysis can be misinterpreted.

The identification of the character of customers' relationships towards banks may be very important also for the marketing practice of banks. It may help the banks' managers not only to better understand the behaviour of their customers, but also to more effectively select the tools for retaining the loyalty of their customers.

\section{References}

1. Akm, E., \& Demirel, Y. (2011). An Empirical Study: Are Corporate Image Relation Satisfaction and Identification with Corporate Influential Factors on Effectiveness of Corporate Communication and Consumer Retention. European Journal of Social Sciences, 23(1), 128-153.

2. Akroush, M. N. (2008). Exploring the mediation effect of service quality implementation on the relationship between service quality and performance in the banking industry in Jordan. Global Business and Economics Review, 10(1), 98-122. http://dx.doi.org/10.1504/ GBER.2008.016830

3. Andreassen, T. W., \& Lindestad, B. (1998). Customer loyalty and complex services. International Journal of Service Industry Management, 9(1), 7-23. http://dx.doi.org/10.1108/09564 239810199923 
4. Balmer, J. (1995). Corporate Branding and Connoisseurship. Journal of General Management, 21(1), 24-46.

5. Balmer, J., \& Stotvig, S. (1997). Corporate identity and private banking: a review and case study. International Journal of Bank. Marketing, 15(5), 169-184. http://dx.doi.org/10.1108/02652 329710175370

6. Beradovic, M., Hultén, Y., \& Petersson, T. (2006). Customer loyalty and satisfaction: A study of Swedbank's small corporate clients in Gothenburg. Bachelor thesis within Business Administration. Jönköping University.

7. Bloemer, J., De Ruyter, K., \& Peeters, P. (1998). Investigating drivers of bank loyalty: the complex relationship between image, service quality and satisfaction. International Journal of Bank Marketing, 16(7), 276-286. http://dx.doi.org/10.1108/02652329810245984

8. Bravo, R., Montaner, T., \& Pina, J. M. (2009). The role of bank image for customers versus non-customers. Internatinal Journal of Bank Marketing, 27(4), 315-334. http://dx.doi.org/10.110 8/02652320910968377

9. Cameran, M., Moizer, P., \& Pettinicchio, A. (2010). Customer satisfaction, corporate image, and service quality in professional services. The Service Industries Journal, 30(3), 421435. http://dx.doi.org/10.1080/02642060802236111

10. Cornelissen, J. (2000). Corporate image: an audience centred model. Corporate Communications: An International Journal, 5(2), 119-125. http://dx.doi.org/10.1108/1356328001 0372540

11. Flavián, C., Torres, E., \& Guinaliu, M. (2004). Corporate image measurement: A further problem for the tangibilization of Internet banking services. International Journal of Bank Marketing, 22(5), 366-384. http://dx.doi.org/ 10.1108/02652320410549665

12. Flavián, C., Guinaliu, M., \& Torres, E. (2005). The influence of corporate image on consumer trust: A comparative analysis in traditional versus internet banking. Internet Research, 15(1), 447-470. http://dx.doi.org/10.1108/10662240510615191

13. Hart, A. E., \& Rosenberg III, P. J. (2004). The Effect of Corporate Image in the Formation of Customer Loyalty: An Australian Replication. Australasian Marketing Journal, 12(3), 88-96. http://dx.doi.org/10.1016/S1441-3582(04)70109-3

14. Hu, H., Kandampully, J., \& Juwaheer, T. D. (2009). Relationships and impacts of service quality, perceived value, customer satisfaction and image: an empirical study. The Service Industries Journal, 29(2), 111-125. http://dx.doi.org/10.1080/02642060802292932

15. Jha, S., Deitz, G. D., Babakus, E., \& Yavas, U. (2013). The Role of corporate image for quality in the formation of attitudinal service loyalty. Journal of Service Research, 16(2), 155 170. http://dx.doi.org/10.1177/1094670512466441

16. LeBlanc,G., \& Nguyen, N. (1996). Cues used by customers evaluating corporate image in service firms: An empirical study in financial institutions. International Journal of Service Industry Management, 7(2), 44-56. http://dx.doi.org/10.1108/09564239610113460

17. Minkiewicz, J., Evans, J., Bridson, K., \& Mavondo, F. (2011). Corporate image in the leisure services sector. Journal of Services Marketing, 25(3), 190-201. http://dx.doi.org/10.1108/08876 041111129173 
18. Nesset, E., Nervik, B., \& Helgesen, Ø. (2011). Satisfaction and image as mediators of store loyalty drivers in grocery retailing. The International Review of Retail, Distribution and Consumer Research, 21(3), 267-292. http://dx.doi.org/10.1080/09593969.2011.588716

19. Nguyen, N., \& LeBlanc, G. (1998). The mediating role of corporate image on customers' retention decisions: an investigation in financial services. International Journal of Bank Marketing, 16(2), 52-65. http://dx.doi.org/10.1108/02652329810206707

20. Onyancha, G. K. (2013). The impact of bank brand image on customer satisfaction and loyalty: A case of Kenya Commercial Bank. European Journal of Business and Management, 5(21), 35-39.

21. Osgood, Ch. E., Suci, G. J., \& Tannenbaum, P. H.(1957). The Measurement of Meaning. Urbana: University of Illinois Press.

22. Van Heerden, C. H., \& Puth, G. (1995). Factors that determine the corporate image of South African banking institutions: an exploratory investigation. International Journal of Bank Marketing, 13(3), 12-17. http://dx.doi.org/10.1108/02652329510082979

23. Wang, Ch. (2010). Service quality, perceived value, corporate image, and customer loyalty in the context of varying levels of switching costs. Psychology \& Marketing, 27(3), 252-262. http://dx.doi.org/10.1002/mar.20330

24. Worcester, R. M. (1997). Managing the image of your bank: the glue that binds. International Journal of Bank Marketing, 15(5), 146-152. http://dx.doi.org/10.1108/02652329710175244

25. Yavas, U., \& Shemwell, D. J. (1996). Bank image: exposition and illustration of correspondence analysis. International Journal of Bank Marketing, 14(1), 15-21. http://dx.doi. org $/ 10.1108 / 02652329610105288$

\section{Contact information}

Doc. PhDr. Rư̌̌ena Lukášová, CSc.

Masaryk University, Faculty of Economics and Administration

Lipová 41a, 60200 Brno, Czech Republic

Email:lukasovar@econ.muni.cz.

Prof. PhDr. Tomás Urbánek, Ph.D.

Academy of Sciences of the Czech Republic, Institute of Psychology

Veverí 97, 60200 Brno, Czech Republic

Email:tour@psu.cas.cz. 